\title{
RETRACTED ARTICLE: Endocrine disruptors in dairy wastewater
}

\section{Kai Cai}

Received: 21 November 2010/Accepted: 13 May 2011/Published online: 21 June 2011 (C) Springer-Verlag 2011

This article has been published OnlineFirst, but has been retracted due to copyright issues that cannot be resolved.

This article has been published OnlineFirst, but has been retracted due to copyright issues that cannot be resolved.

K. Cai $(\square)$

The Institute of Agri-Food and Land Use, School of Biological

Sciences, Queen's University Belfast, Belfast BT9 5AG,

Northern Ireland, UK

e-mail: kacai@ucsd.edu 